\title{
Rafael Lazcano, Tesauro Agustiniano. Tomo V: Castelló-Díez García, Madrid, Uni Cervantes, 2020, 407 pp., $50 €$. ISBN: 978-84-09-01027-1
}

https://doi.org/10.46543/ISID.2130.1011

Hominen unius libri timeo, reza un dicho escolástico atribuido a Santo Tomás de Aquino (1225-1274) y al que parece responder la presente obra Tesauro Agustiniano, integrada - a su vez- por varios volúmenes.

En este proyecto de historia, el lector podrá encontrar una extensa bio-bibliografía sobre la amplia familia agustiniana, desde personajes ilustres que pertenecieron a la Orden de San Agustín a partir del año 1244 —cuya constitución canónica se halla bajo el pontificado de Inocencio IV (1243-1254) - , pasando por los Agustinos Recoletos (tras el año de su fundación en 1588), hasta religiosos o religiosas que, con sus vidas y testimonios continúan engrandeciendo la antes mencionada familia. Hemos de advertir que la procedencia de estos no solo se ceñirá a España, sino también a América Latina, Portugal y Filipinas.

Así, dicha obra se convertirá en algo esencial para todo aquel que desee investigar, estudiar o simplemente conocer algún tema vinculado a cualquier disciplina agustiniana: historia, literatura, ciencia, filosofía, teología, misionología, catequética, pedagogía, iconografía, musicología o hagiografía, entre otras.

Para ello, su autor Rafael Lazcano (1957) — tras más de veinte años de investigación minuciosa - ofrece este tesoro-almacén (thesaurus), con la única finalidad de otorgar a cada lector una extensa, enriquecedora y actual visión acerca de la vida/obra en cada autor biografiado; pero sin olvidarnos que todo lo anteriormente reseñado irá acompañado por una abundante bibliografía que facilite nuestro posterior estudio o investigación.

En este caso, será el Tomo V objeto de nuestra recensión, tomo editado en el año 2020 y que abarcará las voces comprendidas desde la letra C hasta la D, es decir, desde apellidos como Castelló hasta Díez García, engrandeciendo así esta magnum opus et arduum.

En dicha obra, cada bio-bibliografía quedará estructurada en cuatro aspectos claves: 1-Vida; 2- Obras; 3- Fuentes y bibliografía, y 4- Enlace o link, en el caso de que dichas obras se encuentren editadas digitalmente. 
De esta forma, en el presente volumen se nos abrirá un amplio abanico que acogerá tanto a autores del siglo xv (v. gr. Alfonso [Alonso] Martín de Córdoba [ca. 1400-1476]) hasta incluso el mismo siglo xx (v. gr. Gonzalo Díaz García [1929-2014]), ofreciéndonos así un completo y sintético estudio acerca de cada vida, obra y pensamiento sobre dichos autores reseñados.

Todo esto irá precedido por unas"Normas de uso" (p. 9), así como "Abreviaturas y signos convencionales" (p. 10) que nos facilitarán el manejo y estudio del presente volumen, poniendo el punto final un "Índice de nombres" (pp. 397 y ss.).

Por ello, esta obra de Lazcano oferta a nuestro mundo académico e intelectual un elemento indispensable de consulta que otorgará a futuros investigadores la oportunidad de poder llevar a cabo o emprender cualquier proyecto investigativo o trabajo divulgativo.

En nuestra sociedad actual sigue haciéndose necesario las biografías (completadas por una bibliografía que posibilite su futuro estudio de una forma más extensa), puesto que son, sin duda alguna, las que proporcionarán el conocimiento de la historia social, intelectual, religiosa, política y económica.

Son todos estos, pues, motivos que justifican la aparición de esta compleja — aunque sencilla—obra, pues a lo difícil se debe llegar por lo fácil, algo que hará a dicho proyecto literario perdurar en el tiempo y venir a trocarse en referencia.

Pablo Antonio Morillo Rey

Facultad de Teología San Isidoro de Sevilla pabloantoniomr@hotmail.com 